\title{
MARKET OVERREACTION PADA IDX 30 (PERIODE PENELITIAN 2016-2019)
}

\author{
I Gusti Agung Egitha Satria ${ }^{1}$ \\ I Putu Yadnya ${ }^{2}$ \\ ${ }^{1,2}$ Fakultas Ekonomi dan Bisnis Universitas Udayana, Bali, Indonesia \\ ${ }^{1}$ Email: agungegitha@gmail.com
}

\begin{abstract}
ABSTRAK
Ketersediaan informasi yang relevan pada suatu pasar modal khususnya pada sekuritas yang diperdagangkan sangatlah penting bagi investor, sehingga pasar modal dapat dikatakan efisien. Karakteristik investor dapat mengakibatkan pergerakan harga saham. Investor yang bersifat irasional dalam berinvestasi dapat menyebabkan terjadinya makret overreaction. Penelitian ini bertujuan untuk menganalisis keberadaan market overreaction pada IDX 30 periode penelitian 2016-2019. Pengambilan sampel pada penelitian ini menggunakan teknik purposive sampling dan mendapat sampel sebanyak 17 dari 45 populasi perusahaan yang terdaftar pada indeks IDX 30 selama 8 semester. Penelitian ini menggunakan abnormal returns winner, loser, dan loserwinner sebagai variabel penelitian. Pengujian statsitik untuk menguji perbedaan kumulasi ratarata abnormal return saham winner, loser, dan loser-winner dengan menggunakan uji one sample t-test. Hasil penelitian ini menemukan gejala market overreaction pada ACAR portofolio winner, loser, dan ACAR loser-winner yang ditunjukkan dengan adanya pembalik harga (Price Reversal) pada setiap ACAR, namun pengujian signifikansi one sample t-test menunjukkan market overreaction yang terjadi tidaklah signifikan, yang ditunjukkan oleh t-hitung $<\mathrm{t}$-tabel. Kata kunci: Market overreaction, Efisiensi Pasar, Price Reversal, Anomali Winner-Loser
\end{abstract}

\begin{abstract}
The availability of relevant information on a capital market, especially on traded securities, is very important for investors, so that the capital market can be said to be efficient. Investor characteristics can result in Stock Price movements. Investors who are irrational in investing can cause real overreaction. This study aims to analyze the existence of market overreaction on IDX 30 for the 2016-2019 study period. Sampling in this study using purposive sampling technique and got a sample of 17 from 45 population companies listed on the IDX 30 index for 8 semesters. This study uses abnormal returns winner, loser, and loser-winner as research variables. The statistical test used one sample t-test to test for differences in the Average Cumulative Abnormal return of winners, losers, and loser-winners. The results of this study indicate that the occurrence of market overreaction on winner, loser, and ACAR loser-winner portfolios is indicated by the Price Reversal for each ACAR, but the one sample t-test significance test shows that the market overreaction that occurs is not significant. indicated by $t$-count $<t$-table.
\end{abstract}

Keywords: Market overreaction, Market Efficiency, Price Reversal, Winner- Loser Anomaly 


\section{PENDAHULUAN}

Kondisi ekonomi dunia yang tidak menentu, perkembangan investasi pada Bursa Efek Indonesia mendorong para investor lokal maupun asing untuk berinvestasi di pasar modal Indonesia. Terbukti bahwa jumlah investor pasar modal Indonesia meningkat $26 \%$ atau 3,1 juta investor, peningkatan signifikan ini terjadi di tengah pandemi Covid-19 (Abidin, 2020).Pasar modal adalah tempat bertemunya pihak yang memiliki dana lebih dan pihak yang membutuhkan dana yang melakukan transaksi jual beli sekuritas seperti saham dan obligasi yang pada umumnya memiliki kurun waktu jatuh tempo lebih dari satu tahun (Tandelilin, 2017). Investor berinvestasi untuk memperoleh return yang paling optimal. Investor akan berusaha memperoleh informasi yang akurat dan relevan terhadap pasar, sehingga investor akan berpedoman pada Efficient Market Hypothesis $(\mathrm{EMH})$.

Efficient Market Hipotesis menurut (Fama, 1970) pasar efisien merupakan pasar yang harga seluruh sekuritas yang diperdagangkan di pasar telah mencerminkan seluruh informasi yang tersedia. Investor akan bereaksi cepat terhadap informasi baru di pasar efek, dimana informasi tersebut bersifat random, sehingga harga sekuritas yang diperdagangkan dapat berubah menyesuaikan perubahan nilai rill akibat dari adanya informasi yang direspon. Praktiknya, diharapkan investor tidak dapat memanfaatkan informasi internal yang dimilikinya di pasar yang efisien. Dalam praktiknya, sejauh ini masih terdapat fenomena penyimpangan atau anomali. Salah satunya anomali overreaction yang dikemukakan oleh De Bondt dan Thaler pada tahun 1985, yang menguji saham yang terdaftar pada New York Stock Exchange periode penelitian 1926-1982, De Bondt dan Thaler membentuk 50 portofolio winner (kinerja baik) dan 50 portofolio loser (kinerja buruk), dimana dalam literatur tersebut menyatakan bahwa portofolio loser yang terdiri dari saham-saham yang sebelumnya berkinerja buruk, selanjutnya mengalami Price Reversal (pembalik harga) membaik mengungguli portofolio winner pada 36 bulan kemudian dengan pengembalian sebesar $25 \%$ lebih banyak dari portofolio winner (De Bondt \& Thaler, 1985)

Overreaction didasarkan pada asimetri informasi berupa kesenjangan informasi yang diterima investor satu sama lain. Fenomena overreaction, di sisi lain merupakan peluang bagi investor untuk menerapkan strategi kontrarian, yaitu membeli saham saat terjadi over-selling dan bertindak menjual saham saat terjadi pembelian berlebihan (sell high).

Ada beberapa penelitian sebelumnya yang menemukan gejala overreaction dan pembalikan harga, seperti penelitian (Nidar \& Ulfa, 2017) menemukan fenomena Price Reversal serta menemukan faktor-faktor lain seperti, reaksi pasar yang berlebihan, ukuran perusahaan dan January effect berpengaruh terhadap tanda-tanda pembalikan harga, kebijakan deviden, ukuran perusahaan.

(Reddy et al., 2020) "Overreaction Effect: Evidence Froman Emerging Market (ShanghaiStock Market)" menunjukkan bahwa strategi kontrarian menghasilkan pengembalian berlebih (positif), dimana portofolio loser mengalami peningkatan pembalik harga menjadi winner.

(Pedro Piccoli \& Chaudhury, Alceu Souza, 2019) menyelidiki perilaku individu saham AS selama 21 hari perdagangan setelah peristiwa pergerakan 
ekstrim di indeks pasar pada satu hari. Mereka menemukan saham tersebut cenderung bereaksi berlebihan setelah peristiwa positif dan negatif, menunjukkan bahwa reaksi berlebihan dan volatilitas pasar terkait. Mereka mengidentifikasi bahwa reaksi berlebihan didorong oleh kinerja saham-saham yang merugi yang berbalik lebih kuat.

(Shafiq-ur-Rehman, 2019) menguji overriaction pada Pakistan Stock Exchange yang menyatakan reaksi berlebihan hadir pada peristiwa global krisis keuangan yang ditunjukan dari ACAR loser mengungguli ACAR winner.

(Maheshwari \& Dhankar, 2017) melakukan penelitian pada Indian Stock Exchange dengan menggunakan saham bulanan dari 470 saham BSE, hasil penelitiannya menyatakan bahwa pasar modal India memberikan dukungan yang mendukung profitabilitas momentum di pasar saham India yang dimana investor memanfaatkan strategi kontarian dalam mencari return.

(Lerskullawat \& Ungphakorn, 2019) menunjukkan bukti terjadinya reaksi harga saham berlebihan di pasar saham Thailand. (Musnadi et al., 2018) hasil penelitiannya menemukan anomali reaksi berlebihan terjadi di antara portofolio pemenang di seluruh indeks sektoral.

(Sembiring et al., 2016) yang menemukan reaksi pasar terjadi di pasar saham Indonesia yang ditandai dengan return pembalikan saham winner dan loser. (Pokavattana et al., 2019) Hasil penelitiannya menunjukkan bahwa terdapat overreaction di pasar modal Thailand ditunjukkan oleh CAR portofolio loser mengungguli portofolio winner.

(Alves, 2020) menguji 49 indeks dari Indeks Morgan Stanley Capital International periode 1970-2018, bukti untuk hipotesis reaksi berlebihan ditemukan ketika periode investasi 5 tahun, portofolio loser tidak hanya mengungguli portofolio winner, tetapi portofolio loser juga kurang berisiko dibandingkan portofolio winner.

(Gumanti et al., 2019) menguji indeks LQ-45 pada peristiwa ASIAN GAMES dan terjadi reaksi pasar yang berlebihan dalam the winner and loser portfolios karena pengumuman Indonesia untuk menjadi tuan rumah Asian Games ke-18, pembalikan harga terjadi pada portofolio loser saja.

(Melisa Tanady, 2020) melakukan penelitian dengan menganalisis market overreaction dengan size effect pada LQ45 tahun 2015-2019, hasil penelitiannya market overreaction terjadi dalam jangka pendek maupun jangka panjang.

Beberapa hasil penelitian lain yang tidak menemukan reaksi berlebihan atau pembalikan harga, seperti penelitian (Dewanthi \& Wiksuana, 2017) hasil pengujian yang dilakukan pada indeks BISNIS-27 menyatakan bahwa hasil penelitiannya tidak menemukan overreaction secara signifikan ditandai dengan adanya abnormal return portofolio winner mengungguli abnormal return portofolio loser.

(Surya Pratama, 2016) penelitiannya menunjukkan market overreaction pada perusahaan manufaktur tahun 2014 tidak terjadi, ditandai secara signifikan abnormal return saham winner unggul dari abnormal return saham loser.

(Hadimas, 2019) secara statistik tidak terjadi overreaction sehingga strategi kontrarian atau strategi pembalik tidak dapat dimanfaatkan pada indeks LQ 45 pada Bursa Efek Indonesia. 
(Zakir R et al., 2019) hasil penelitian mereka yang meneliti saham perusahaan manufaktur yang terdaftar di (BEI) periode 2015-2017, menyimpulkan bahwa kinerja portofolio loser tidak mengungguli portofolio pemenang kinerja selama masa studi.

(Rahmah, 2018) meneliti saham BUMN (IDX BUMN20) dan Non BUMN 2013-2017, hasilnya tidak terjadi pembalikan return secara signifikan pada saham BUMN baik porotofolio winner maupun loser. Sebaliknya terjadi pembalikan return secara signifikan pada saham Non BUMN di beberapa periode pengujian.

(Caporale \& Plastun, 2019) meneliti overreaction pada harga dalam kasus mata uang kripto seperti bitcoin, litecoin, riak, dan dasbor hasil penelitiannya tidak menemukan reaksi berlebih sehingga konsisten terhadap teori EMH.

Overreaction tidak terjadi pada saham perusahaan manufaktur dalam indeks LQ-45 dapat dibuktikan dengan pola portofolio winner mengungguli portofolio loser (Novisiantara et al., 2017).

(Puspitasari et al., 2020) menguji overreaction terhadap harga saham setelah adanya pengumuman work from home pada LQ 45 Hasil pengujian ini juga menunjukkan bahwa portofolio loser tidak mengungguli portofolio winner.

(Joshua Duta Wacana, 2017) hasil penelitianya menunjukkan saham LQ-45 periode 2013-2015 di BEI meskipun mengalami beberapa gejala overreaction namun menunjukkan hasil yang tidak signifikan dan strategi kontarian tidak dapat dilakukan

Beberapa hasil penelitian terdahulu yang argumentasi hasilnya bervariasi mengenai overreaction maka menarik untuk dilakukan penelitain lebih lenjut. Sehubungan dengan hal tersebut menarik untuk dilakukan pengujian terhadap indeks IDX 30 sebagai objek penelitian karena IDX 30 merupakan indeks terlikuid yang terdiri dari 30 saham yang dipilih dari konstituen indeks LQ45 yang di luncurkan pada tanggal 23 April 2012 oleh BEI. Indeks IDX 30 memiliki likuiditas tinggi dan kapitalisasi pasar besar serta di dukung oleh fundamental perusahaan emiten yang baik sehingga cukup efektif untuk mengambarkan pergerakan saham.

Periode penelitian dilakukan pada awal 2016-2019. Pada rentang waktu periode penelitian selama 48 bulan tersebut terdapat momentum peristiwa yang mempengaruhi harga pasar saham yang terdaftar pada Bursa Efek Indonesia. Pada tahun 2018 terdapat momentum fenomena perang dagang Amerika Serikat dengan Tiongkok bermulai setelah Presiden Amerika Serikat Donald Trump ingin menaikkan bea masuk produk-produk yang berasal dari Tiongkok pada 22 Maret 2018.

Fenomena lainnya yang tengah melanda dunia pada saat ini yaitu fenomena pandemi covid-19 yang terjadi pada akhir tahun 2019 hingga saat ini dan fenomena lainnya. Melihat fenomena pergerakan IHSG sebagai indikator pergerakan harga saham BEI yang mencakup pergerakan harga seluruh saham biasa dan saham preferen yang tercatat di BEI.

Fenomena-fenomena tersebut baik yang terjadi di dalan negeri maupun yang terjadi diluar negeri, dapat mempengaruhi pergerakan suatu perekonomian dinia bahkan dapat mempengaruhi pasar modal di seluruh dunia, pengaruh fenomena atau peristiwa tersebut Nampak pada pergerakan IHSG pasar modal. 
Adanya momentum yang bersifat mikro maupun makro dapat menyebabkan fluktuasi pada IHSG Bursa Efek Indonesia seperti grafik berikut.

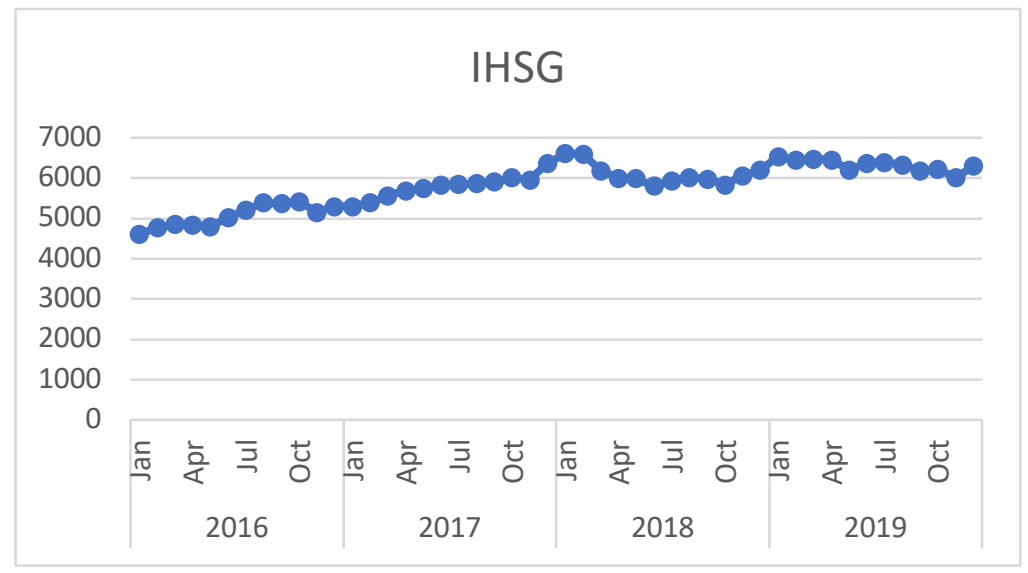

Gambar 1. Fluktuasi IHSG Bursa Efek Indonesia

Sumber: (Investing.com, 2020)

Adanya gap antara teori dengan hasil penelitian, dan adanya inkonsisten hasil penelitian dari berbagai penelitian terdahulu, serta terdapat momentum yang bersifat makro maupun mikro, maka penulis sangat tertarik untuk menganalisis reaksi pasar berlebih pada IDX 30.

Efficient Market Hypothesis (Teori Pasar Efisien) yang dikemukakan pertama kali oleh Eugene Fama pada awal tahun 1970 ia menyatakan bahwa harga seluruh sekuritas yang diperdagangkan di pasar telah mencerminkan seluruh informasi yang tersedia, dimana sebuah informasi berpengaruh terhadap respon investor. Fama menyatakan terdapat 3 bentuk pasar efisien, yaitu bentuk pasar efisien lemah (weak), bentuk setengah kuat (semi-strong) dan bentuk kuat (strong),

Menurut (Hartono, 2017:605) Pasar yang efisien adalah pasar yang bereaksi dengan cepat dan akurat menuju posisi harga ekuilibrium baru, yang mencerminkan informasi yang tersedia sepenuhnya. Event study berusaha mendeteksi respon pasar terhadap sesuatu peristiwa atau informasi yang di publikasikan. Kandungan informasi yang melekat dalam suatu peristiwa yang dipublikasikan akan menghasilkan respon pasar yang berbeda. Kecepatan dan ketepatan respon pasar akan mempengaruhi harga saham dan tingkat abnormal return, dimana abnormal return positif untuk good news sedangkan abnormal return negatif untuk bad news.

Anomali pasar (market anomaly) merupakan suatu strategi atau teknik yang bertentangan dengan pasar efisien (Jones 1996 dalam Hartono, 2017:644). Salah satu anomali pasar adalah reaksi pasar berlebih (market overreaction).

Pengamatan paling awal mengenai reaksi berlebih di pasar dibuat oleh J. M. Keynes (De Bondt \& Thaler, 1985). De Bondt dan Thaler dalam penelitiannya pada tahun 1985, yang menguji saham yang terdaftar pada New York Stock Exchange periode penelitian 1926-1982, Debont dan Thaler membentuk 50 portofolio winner dan 50 portofolio loser dimana dalam literatur tersebut menyataka bahwa portofolio loser yang terdiri dari saham-saham yang 
sebelumnya berkinerja buruk selanjutnya dapat membaik mengungguli portofolio winner pada 36 bulan kemudian dengan pengembalian sebesar $25 \%$, terbukti dari adanya pengembalian Januari yang sangat besar hingga lima tahun setelah pembentukan portofolio.

De Bondt dan Thaler (1985) menyatakan bahwa implikasi dari market overreaction adalah investor disarankan untuk membeli saham loser dan menjual saham ketika saham loser tersebut sudah menjadi saham winner karena dalam jangka panjang akan terjadi pembalikan harga sehingga investor dapat memperoleh keuntungan capital gain, dimana saham yang merugi akan mengalami pembalikan harga hal ini disebut dengan strategi kontarian atau yang disebut dengan strategi berlawanan (Sembiring et al., 2016).

Market overreaction dapat dilihat dari nilai CAR. Pembentukan 20\% CAR teratas portofolio winner dan $20 \%$ terbawah sebagai portofolio loser. Pembentukan portofolio dengan proporsi $20 \%$ disesuaikan dengan jumlah sampel yang digunakan dan menyesuaikan dengan metode equally weighted method.

Hipotesis Overreaction menyatakan bahwa saham-saham yang berkinerja buruk pada pasar selama periode waktu tertentu (sering kali satu sampai lima tahun) akan mengungguli pasar selama periode waktu berikutnya. Pernyataan ini pertama kali dicatat oleh (De Bondt \& Thaler, 1985) yang menemukan reversal effect, menggunakan data saham New York Stock Exchange dari tahun 1926 hingga 1982, bahwa portofolio loser sebelumnya mengungguli portofolio winner sebelumnya dengan hampir $25 \%$ di atas periode tiga tahun berikutnya. Price Reversal terjadi kerana tindakan berlebihan investor, sehingga hal ini merupakan tanda terjadinya overreaction. Saham yang meningkat secara ekstrim disebut saham winner dan saham yang mengalami penurunan secara ekstrim disebut sebagai saham loser.

Peristiwa market overreaction menyebabkan terjadinya kecenderung harga sekuritas melewati harga pasarnya sehingga mengakibatkan terjadinya pembalikan harga atau biasanya dikenal dengan Price Reversal. Price Reversal merupakan salah satu anomaly yang bertentangan dengan Efficient Market Hipotesis. Kecenderungan portofolio yang memiliki kinerja yang buruk (loser) dapat berbalik menjadi portofolio yang memiliki kinerja yang baik (winner) pada periode berikutnya dan sebaliknya. Overreaction dalam jangka pendek (yang dapat menimbulkan momentum harga) akan mendorong pembalikan (reversal) dalam jangka panjang ketika pasar mengakui kesalahan masa lalu. Seperti penelitian terdahulu yang dilakukan oleh (Nidar \& Ulfa, 2017) menemukan fenomena pembalikan harga/Price Reversal serta ditemukannya faktor-faktor lain seperti, reaksi pasar yang berlebihan, ukuran perusahaan dan January effect berpengaruh terhadap tanda-tanda pembalikan harga, kebijakan dividen, ukuran perusahaan.

Para investor melakukan kegiatan investasi di pasar modal khususnya pada instrument investasi mengharapkan keuntungan dimasa datang. Para investor akan berlomba-lomba berusaha untuk mencari return dan keuntungan yang semaksimal mungkin atau return yang paling optimal. Return menurut (Tandelilin, 2017:113) adalah suatu faktor yang memotivasi para investor dalam berinvestasi dan sebagai imbalan atas keberanian investor dalam melakukan investasi yang dilakukannya. Menurut (Tandelilin, 2017:51) return terdiri dari dua komponen yaitu capital gain(loss) dan yield. Yield merupakan return yang mencerminkan aliran kas berupa pendapatan yang diperoleh dari suatu investasi yang diperoleh secara periodik, 
yield tersebut dapat berupa dividen saham yang dibagikan oleh pihak emiten kepada para investornya. Capital gain(loss) merupakan selisih harga saham yang menunjukan kenaikan atau penuruna harga instrument invetasi yang dapat memberikan keuntungan atau kerugian bagi investor. Capital gain dapat diperoleh jika selisih harga jual lebih besar dari harga beli, sebaliknya jika selisih harga beli lebih besar dari harga jual maka hal ini disebut dengan capital loss.

Abnormal return merupakan selisih antara actual return dengan expected return. Terdapat tiga jenis abnormal return menurut (Hartono, 2017:682) yaitu :

Average Abnormal return (AAR). Average abnormal return merupakan ratarata abnormal return dari seluruh jenis saham yang dianalisis secara harian. AAR dapat bernilai positif maupun negatif selama kurun window period.

Cummulative Abnormal return (CAR). Cummulative abnormal return merupakan komulatif harian abnormal return saham dari hari pertama hingga harihari berikutnya. CAR periode sebelum peristiwa akan dibandingkan dengan CAR periode setelah peristiwa terjadi, untuk mengetahui jenis saham berpengaruh positif ataupun negatif.

Average Cummulative Abnormal return (ACAR). Merupakan komulatif harian CAR mulai hari pertama sampai hari berikutnya. ACAR dapat menghitung kecenderungan kenaikan ataupun penurunan yang terjadi selama window period sehingga dapat mengetahui dampak positif maupun negatif saham yang diteliti.

Kerangka konsep penelitian pada gambar tersebut menjelaskan bahwa peristiwa yang akan diuji dalam analisis teknikal event study ini adalah fenomena market overreaction pada IDX 30. Terlebih dahulu mencari close Price sampel penelitian, selanjutnya menghitung return bulanan saham (actual return) dan return bulanan pasar (expected return). Setelah menghitung return maka tahap selanjutnya ialah menghitung abnormal return (selisih actual return dan expected return).

Menghitung Cumulative Abnormal return (CAR) periode penelitian dan membentuk $20 \%$ teratas portofolio winner dan 20\% terbawah sebagai portofolio loser, selanjutnya melakukan perhitungan Average Abnormal return (AAR), langkah selanjutnya menghitung Cummulative Average Abnormal return (CAAR) pada tahap ini mulai terlihat overreaction, tahap terakhir yaitu menghitung Average Cumulative Abnormal return (ACAR).

Pembuktian adanya overreaction pada IDX 30 dapat dilihat dari adanya perbedaan hasil ACAR winner dan loser, kemudian untuk mengetahui signifikansi overreaction dapat menggunakan one sample t-test untuk menguji tingkat signifikan nilai ACAR loser dan ACAR winner yang mungkin mengalami pembalik harga pada masing-masing periode pengujian secara signifikan dilihat dari output one sample t-test pada pengujian hipotesis.

Market overreaction terjadi dikarenakan adanya kesenjangan informasi yang diterima oleh setiap investor. Investor yang irasional akan spontan melakukan penjualan atau pembelian saham dan pada akhirnya dapat menyebabkan Price Reversal. Kerangka konseptual dijabarkan pada gambar di bawah ini 

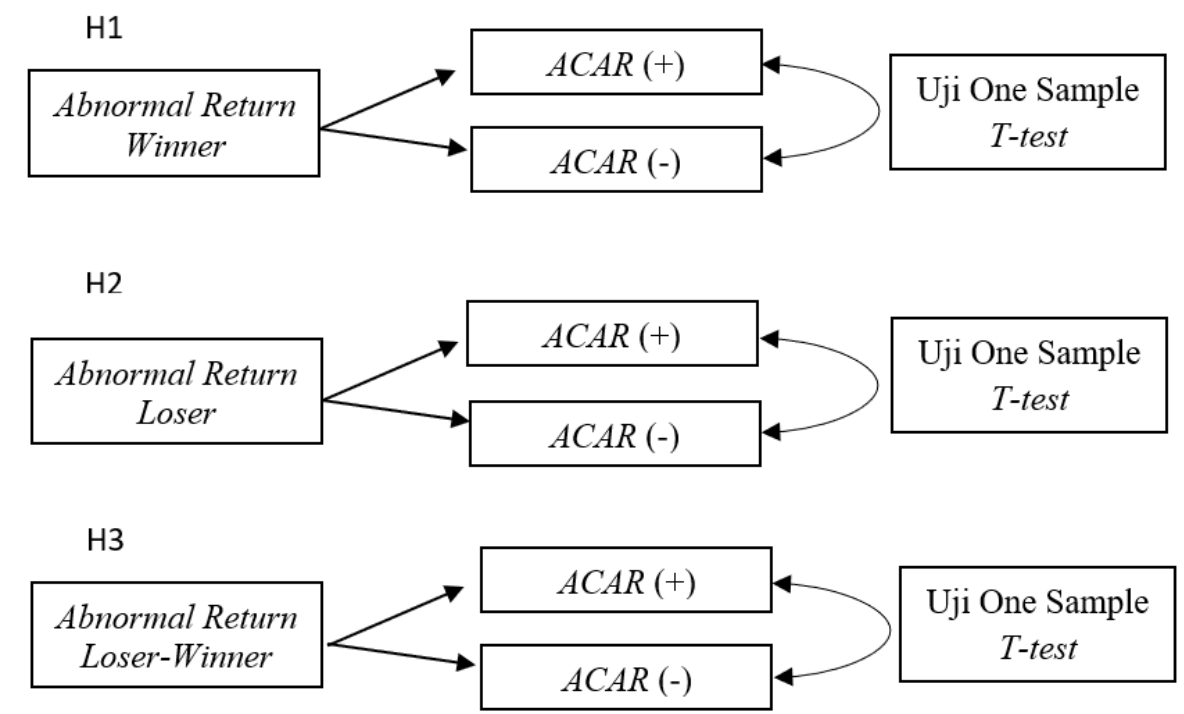

\section{Gambar 2. Kerangka Konseptual}

Sumber: data diolah, 2020

Penelitian yang dilakukan (Nidar \& Ulfa, 2017) pada saham yang terdaftar di Jakarta Islamic Index dimana hasil penelitian tersebut menjelaskan terjadinya reaksi pasar yang berlebihan, kebijakan dividen, ukuran perusahaan dan January effect berpengaruh terhadap tanda-tanda pembalikan harga secara signifikan. (Sembiring et al., 2016) penelitinnya menemukan reaksi berlebih (market overreaction) disertai pembalik harga (Price Reversal) ditandai dengan return pembalikan saham winner dan loser.

Beberapa penelitian sebelumnya yang tidak menemukan anomali pembalikan harga atau reaksi berlebihan seperti penelitian (Praditha et al., 2019) menguji reaksi pasar sebelum dan sesudah implementasi acara Asian Games 2018 dimana hasil penelitiannya menunjukkan bahwa reaksi pasar berlebihan tidak terjadi ditunjukkan dengan portofolio saham loser tidak mempertahankan pembalikan harga untuk berbalik ke dalam portofolio saham winner dan sebaliknya. Riset dengan studi peristiwa dapat menguji informasi yang relevan dengan pasar.

Berdasarkan kajian teoritis dan inkonsisten hasil penelitian terdahulu, sehingga rumusan hipotesis penelitian ini dirumuskan sebagai berikut:

$\mathrm{H}_{1}$ : Portofolio winner secara signifikan lebih kecil dari pada portofolio loser.

$\mathrm{H}_{2}$ : Portofolio loser secara signifikan lebih besar dari pada portofolio winer.

$\mathrm{H}_{3}$ : Portofolio loser-winner lebih besar dari 0.

\section{METODE PENELITIAN}

Desain yang digunakan oleh penelitian ini adalah analisis deskriptif kuantitatif untuk mengetahui anomali market overreaction dan Price Reversal pada indeks saham yaitu IDX 30 periode 2016-2019 yang dilakukan di Bursa Efek Indonesia dengan mengakses pada website resmi yaitu: www.idx.co.id dan www.yahoofinance.com. Penelitian ini dilakukan mulai bulan Agustus 2020, dengan mengambil data indeks saham IDX 30 selama periode 2016-2019. Obyek penelitian ini adalah portofolio yang terdaftar dalam indeks IDX 30 periode 
2016-2019 yang terdaftar di BEI.

Ditinjau dari rumusan masalah beserta hipotesis penelitian yang telah disusun di atas, maka penelitian ini akan menganalisis reaksi pasar berlebih yang diproksikan dalam abnormal return portofolio winner, portofolio loser dan portofolio loser-winner sebagai variabel penelitian ini terhadap IDX 30 Periode 2016-2019.

Variabel penelitian tersebut akan diuji untuk menguji reaksi berlebih dari investor pada indek saham IDX 30 yang terdaftar di Bursa Efek Indonesia pada periode Januari 2016-2019. Abnormal return diperoleh dari selisih return saham dengan return pasar. Pengelompokan portofolio winner, loser dan loser-winner diperoleh dari perhitungan Cummulative Abnormal return dengan proporsi sebesar $20 \%$ teratas sebagai portofolio winner dan proporsi $20 \%$ terbawah sebagai portofolio loser.

Variable penelitian ini terdiri dari tiga yaitu: Abnormal return portofolio winner. Abnormal return portofolio winner merupakan portofolio yang terdiri dari saham-saham yang memiliki kinerja yang baik yang menghasilkan abnormal return bernilai positif. Kedua, abnormal return portofolio loser. Abnormal return portofolio loser merupakan portofolio yang terdiri dari saham-saham yang memiliki kinerja yang buruk yang menghasilkan abnormal return bernilai negatif. Ketiga, abnormal return portofolio loser-winner. Abnormal return portofolio loser-winner merupakan selisih saham-saham yang berkinerja buruk (loser) yang menghasilkan abnormal return negative dengan saham-saham yang berkinerja baik (winner) yang menghasilkan abnormal return positif.

Langkah-langkah pengujian market overreaction pada IDX 30 yang diproksikan dalam abnormal return dan saham winner loser dengan menghitung Actual return

$R_{i, t}=\frac{P_{t}-P_{t-1}}{P_{t-1}}$

Keterangan:

$\mathrm{R}_{\mathrm{i}, \mathrm{t}} \quad$ : Return individu saham i pada waktu $\mathrm{t}$.

$\mathrm{P}_{\mathrm{t}} \quad$ : Close Price saham i pada waktu t.

$\mathrm{P}_{\mathrm{t}-1}$ : Close Price saham i pada saat sebelum waktu $\mathrm{t}$.

Market return

$R_{m, t}=\frac{I H S G_{t}-I H S G_{t-1}}{I H S G_{t-1}}$

Keterangan:

$\mathrm{R}_{\mathrm{m}, \mathrm{t}} \quad$ : Return pasar waktu $\mathrm{t}$.

$\mathrm{IHSG}_{\mathrm{t}}$ : Indeks Harga Saham Gabungan waktu t.

IHSG $_{\mathrm{t}-1} \quad$ : Indeks Harga Saham Gabungan sebelum waktu t.

Abnormal return

$A R_{i, t}=R_{i, t}-E_{m, t}$

Keterangan:

$\mathrm{AR}_{\mathrm{i}, \mathrm{t}} \quad$ : Return tak normal saham i pada waktu t.

$\mathrm{R}_{\mathrm{i}, \mathrm{t}} \quad$ : Return individu saham i pada waktu $\mathrm{t}$.

$\mathrm{E}_{\mathrm{m}, \mathrm{t}} \quad$ : Return pasar pada waktu $\mathrm{t}$. 
Cummulative abnormal return (CAR).

$C A R_{i}=\sum_{t=1}^{n} A R_{i, t}$

Keterangan:

$\mathrm{CAR}_{\mathrm{i}}$ : Cummulative abnormal return perusahaan $\mathrm{i}$ pada periode $\mathrm{t}$, yang diakumulasikan dari $\mathrm{AR}_{\mathrm{i}, \mathrm{t}}$ sekuritas ke-i.

$\mathrm{AR}_{\mathrm{i}, \mathrm{t}}$ : Abnormal return sekuritas ke-i.

Average abnormal return (AAR)

$A A R_{t}=\frac{\sum_{i=1}^{k} A R_{i t}}{k}$

Keterangan:

$A A R_{t} \quad$ : Rata-rata return tak normal pada bulan ke-t.

$A R_{i t} \quad$ : Return tak normal sekuritas ke-i pada bulan ke-t.

$\mathrm{k} \quad$ : Jumlah sekuritas yang terpengaruh oleh pengumuman peristiwa.

Cummulative average abnormal return (CAAR)

$C A A R=\sum_{t=1}^{n} \frac{A A R_{t}}{n}$

Keterangan:

$A C A R_{t}$ : Cumulative Average Abnormal return bulan ke-t.

$A C A R_{i t} \quad:$ Average Abnormal return sekuritas ke-i bulan ke-t.

$\mathrm{n} \quad$ : Jumlah sampel sekuritas.

Average cummulative abnormal return (ACAR).

$A C A R_{t}=\sum \frac{C A A R}{z}$

Keterangan:

ACAR $_{t}$ : Average cummulative abnormal return ke-t.

CAAR : Nilai CAAR (penjumlahan) portofolio.

Z : Jumlah replikasi ke-t

Jenis data penelitian ini adalah data kuantitatif berupa close Price indeks saham IDX 30 yang terdaftar di BEI pada periode 2016-2019. Data yang digunakan dalam penelitian ini adalah data closing Price bulanan selama 48 bulan. Harga saham bulanan tersebut digunakan sebagai perhitungan abnormal return masingmasing saham IDX 30. Data kualitatif berupa daftar nama emiten yang tergabung dalam IDX 30 periode 2016-2019. Sumber data yang digunakan dalam penelitian ini adalah sata sekunder berupa indeks IDX 30 yang didapatkan melalui website resmi www.idx.co.id, www.yahoo.finance.com dan www.investing.com.

Populasi dalam penelitian ini adalah seluruh saham yang masuk dalam Indeks IDX 30. IDX 30 dikaji setiap semester dengan perhitungan free float sehingga setiap semester ada emiten baru yang terdaftar pada IDX 30 dan ada yang tereliminasi, sehingga total populasi penelitian selama 8 semester selama periode 2016-2019 sebanyak 45 emiten.

Sample penelitian sebanyak 17 sampel dengan menggunakan metode purposive sampling. Ketentuan kriteria pengambilan sampel metode purposive 
sampling dijabarkan dibawah ini: Emiten yang terpilih menjadi sampel penelitian ini adalah emiten yang telah dan masih tercatat di BEI periode 2016-2019. Emiten yang tercatat pada indeks IDX 30 dan terdaftar konsisten selama periode studi 2016-2019. Secara continue selama masa studi 2016-2019. Data saham perusahaan dan informasi yang terdaftar lengkap yang tersedia selama periode penelitian 20162019.

Pengumpulan data yang dilakukan dalam penelitian ini diperoleh dengan cara observasi non partisipan data penelitain diperoleh pada Bursa Efek Indonesia yang diakses dari website resmi www.idx.co.id, www.investing.com dan www.finance.yahoo.com. Data yang telah terkumpul akan diolah sama halnya dengan teknik analisis yang digunakan oleh De Bondt dan Thaler pada tahun 1985 yaitu dengan melakukan dua proses analisis, yaitu periode pembentukan portofolio dan periode pengujian.

Pembentukan portofolio dilakukan setiap tahun dan periode pengujian dilakukan pada tahun-tahun setelah periode pembentukan secara bergantian dan seterusnya selama periode tahun 2016-2019. Analisis data yang telah diperoleh dari penelitian kemudian dianalisis untuk menguji signifikansi hipotesis penelitian. Pengujian hipotesis ACAR winner mengalami pembalik (menjadi negatif) hal tersebut tidak signifikan apabila t-hitung $\geq \mathrm{t}$-tabel, artinya tidak terjadi overreaction secara signifikan, begitu sebaliknya. ACAR loser mengalami pembalikan (menjadi positif) hal tersebut tidak signifikan apabila t-hitung $\leq \mathrm{t}$-tabel, maka overreaction tidak signifikan, begitu pula sebaliknya. Selisih ACAR ini gunakan untuk melihat apakah kinerja portofolio loser dapat melampaui kinerja portofolio winner atau tidak, apabila selisih ACAR loser-winner menjadi positif maka terjadi overreaction. Akan tetapi pembalikan (menjadi positif) tersebut tidak signifikan apabila jika t-hitung $\leq \mathrm{t}$-tabel, maka overreaction tidak signifikan, dan sebaliknya.

Uji yang dilakukan terlebih dahulu yaitu diadakan uji prasyarat analisis dengan uji normalitas agar data berdistribusi normal maka, Menurtu (Utama, 2016) uji normalitas merupakan uji prasyarat menguji apakah data yang di buat berdistribusi normal atau tidak. langkah selanjutnya adalah melakukan pengujian dengan uji parametrik one sample t-test menggunakan software SPSS agar mendapatkan hasil yang lebih akurat untuk menguji perbedaan nilai ACAR secara signifikan dari mean sampel. Tingkat signifikansi $0,05(\alpha=5 \%)$ dan nilai t-hitung tiap periode lebih kecil dibandingkan dari nilai t-tabel.

\section{HASIL DAN PEMBAHASAN}

Gambaran umum objek penelitian ini mengacu pada analisis yang dilakukan untuk mengetahui gejala overreaction pada indeks IDX 30 periode penelitian 20162019. Overreaction terjadi karena adanya kesenjangan informasi. Abnormal return portofolio winner, loser dan loser-winner sebagai variabel untuk menganalisis gejala overreaction pada IDX 30. Indeks IDX30 merupakan indeks yang terdiri dari 30 saham yang dipilih dari konstituen Indeks yang dikaji setiap semester dengan menggunakan perhitungan free float, sehingga terdapat 8 semseter dalam periode penelitian 2016-2019. Populasi penelitian ini sebanyak 45 emiten.

Saham-saham IDX 30 hanya 17 perusahaan yang menjadi sampel penelitian ini. Pemilihan sampel menggunakan metode purposive sampling dengan beberapa kriteria, seperti perusahaan yang sudah dan masih terdaftar selama periode 2016- 
2019, kedua adalah perusahaan konsisten berada di indeks IDX 30 selama periode 2016-2019, dan ketiga data perusahaan tersedia secara lengkap. Pengolahan data sampel menghasilkan output berupa return saham, return pasar, abnormal return, CAR, AAR, CAAR dan nilai ACAR untuk masing-masing portofolio winner, loser dan loser-winner setiap periode penelitian.

Pembentukan formasi cumulative Abnormal return (CAR) sampel dengan mengurutkan dari urutan terbesar hingga terkecil. Selain itu, 20\% teratas dan $20 \%$ terbawah diambil untuk pembentukan portofolio winner dan loser dari setiap replikasi. Penentuan pembentukan portofolio dilakukan dengan cara yang dilakukan De Bondt \& Thaler serta para peneliti terdahulu yang meggunakan equally-weighted method dalam perengkingan pembentukan portofolio. Hasil pembentukan portofolio dapat dilihat pada tabel berikut:

Tabel 1.

Portofolio Winner dan Loser

\begin{tabular}{ccccc}
\hline Tahun & Kode Saham & CAR Winner & Kode Saham & CAR Loser \\
\hline $\mathbf{2 0 1 6}$ & ADRO & 1,1588 & LPPF & $-0,2536$ \\
& INDF & 0,3300 & SMGR & $-0,3479$ \\
& ASII & 0,2004 & INTP & $-0,4939$ \\
$\mathbf{2 0 1 7}$ & BBNI & 0,4352 & INDF & $-0,2141$ \\
& UNTR & 0,3473 & LPPF & $-0,5249$ \\
& BBRI & 0,2799 & PGAS & $-0,6027$ \\
$\mathbf{2 0 1 8}$ & PGAS & 0,3798 & UNTR & $-0,1905$ \\
& SMGR & 0,2853 & ADRO & $-0,3079$ \\
& BBCA & 0,2068 & LPPF & $-0,4622$ \\
$\mathbf{2 0 1 9}$ & ADRO & 0,2892 & ASII & $-0,1699$ \\
& BBCA & 0,2379 & UNTR & $-0,2260$ \\
& BBRI & 0,1774 & GGRM & $-0,4255$ \\
\hline
\end{tabular}

Sumber: data diolah, 2020

Adanya reaksi berlebihan dapat dilihat pada hasil CAAR dan ACAR, serta dengan menguji signifikansi hipotesis. Menghitung statistic one sample t-test untuk menguji signifikansi hipotesis. Pengujian ketiga hipotesis menggunakan uji-t satu sampel (hipotesis 1 dengan left-tailed dan hipotesis 2 dan 3 dengan right-tailed).

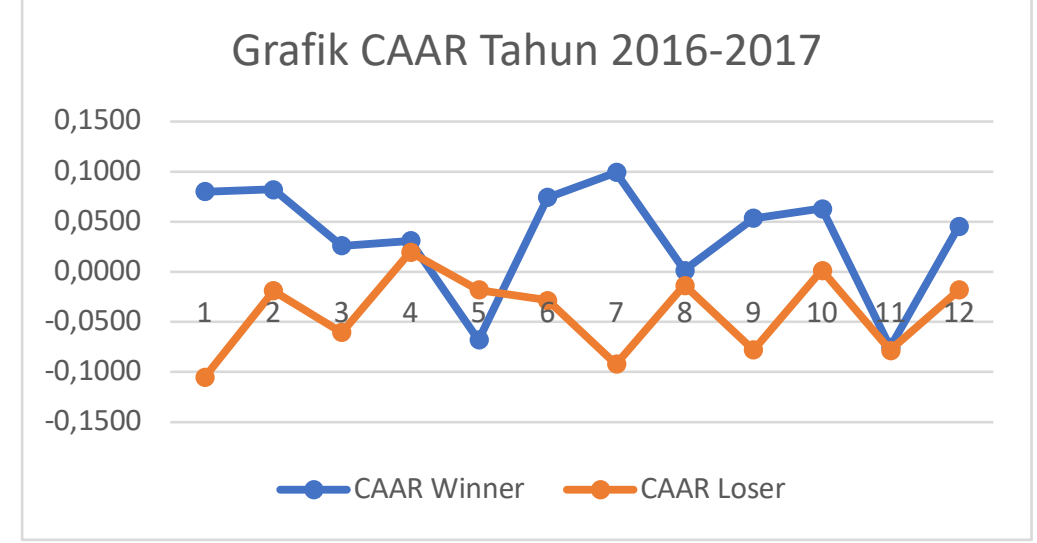

Gambar 3. CAAR Replikasi Pertama (2016-2017)

Sumber: Data diolah, 2020 
Replikasi pertama periode pembentukan tahun 2016. Tahun 2016 sebagai periode pembentukan dan tahun 2017 sebagai periode pengujian. Formasi portofolio winner adalah ADRO, INDF, ASII. Selama periode replikasi pertama saham winner yang menghasilkan nilai CAAR tertinggi terjadi pada bulan Juli sebesar $9,9 \%$. Nilai CAAR winner yang mengalami pembalik harga (negatif) terjadi pada bulan Mei menjadi $-6,8 \%$, bulan November menjadi $-7,5 \%$. Selama periode replikasi pertama saham loser menghasilkan nilai CAAR tertinggi pada bulan April sebesar $1,9 \%$. Nilai CAAR loser yang mengalami pembalik harga (positif) terjadi pada bulan April sebesar 1,9\%, dan bulan Oktober menjadi 0,1\%.

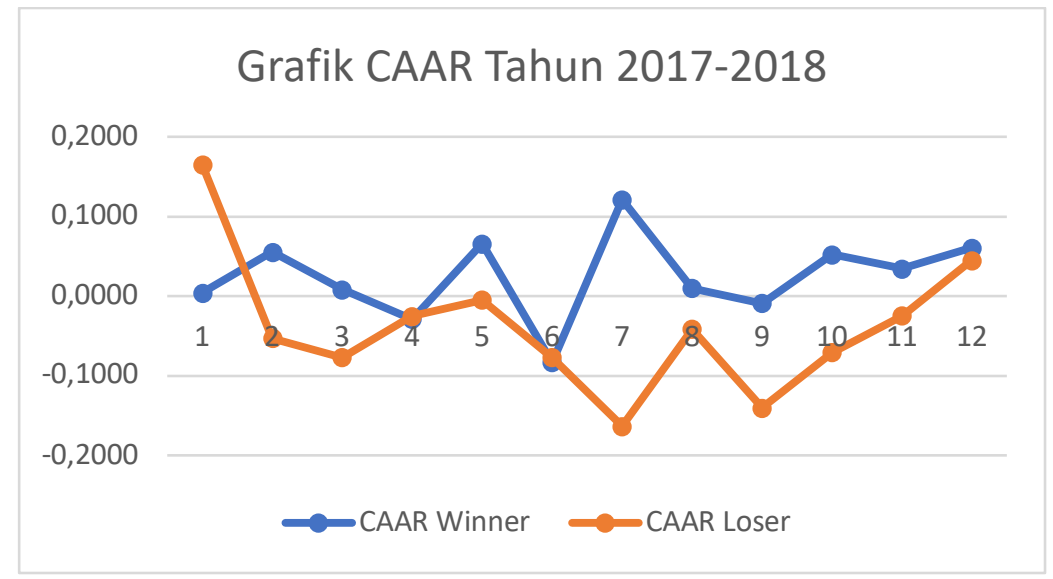

Gambar 4. CAAR Replikasi Kedua (2017-2018)

Sumber: Data diolah, 2020

Replikasi kedua periode pembentukan tahun 2017 dan tahun 2018 digunakan sebagai periode pengujian tahun 2017. Formasi portofolio winner adalah BBNI, UNTR, dan BBRI. Selama periode replikasi kedua saham winner yang menghasilkan nilai CAAR tertinggi terjadi pada bulan Juli sebesar 12,1\%. Nilai CAAR winner yang mengalami pembalik harga (negatif) terjadi pada bulan April menjadi $-2,9 \%$, bulan Juni menjadi $-8,3 \%$, bulan September menjadi -0,9\%.

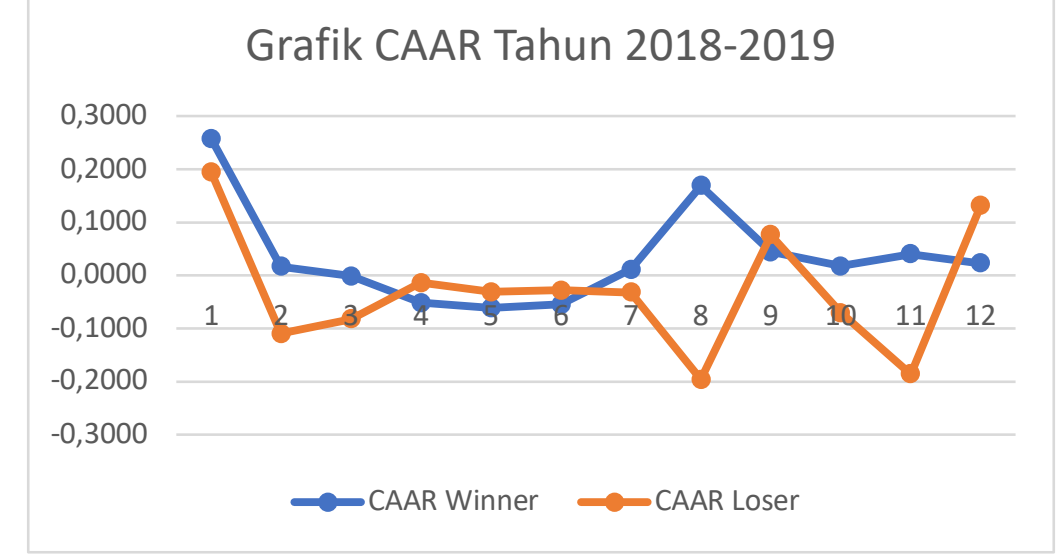

\section{Gambar 5. CAAR Replikasi Kedua (2018-2019)}

Sumber: Data Dioalah, 2020

Replikasi ketiga periode pembentukan tahun 2018 dan tahun 2019 sebagai 
periode pengujian. Formasi portofolio winner adalah PGAS, SMGR, dan BBCA. Selama periode replikasi kedua nilai CAAR saham winner tertinggi pada bulan Januari sebesar $25,7 \%$. Nilai CAAR winner yang mengalami pembalik harga (negatif) terjadi pada bulan Maret menjadi -0,1\%, bulan April menjadi -5,2\%, dan bulan Mei menjadi $-6,1 \%$ dan bulan Juni sebesar-5,5\%.

Nilai CAAR loser yang mengalami pembalik harga (positif) terjadi pada bulan Januari menjadi 19,4\%, bulan September sebesar 7,6\%, dan bulan Desember menjadi $13,1 \%$. Uji selanjutnya adalah pengujian terhadap seluruh replikasi, dengan melakukan. Perhitungan one sample t-test sebagai berikut.

Tabel 2 .

Pengujian Portofolio Winner

\begin{tabular}{|c|c|c|c|c|c|c|c|c|c|c|c|c|}
\hline \multirow[b]{2}{*}{ Replikasi } & \multicolumn{12}{|c|}{ CAAR Winner } \\
\hline & Jan & Feb & $\begin{array}{c}\mathbf{M a} \\
\mathbf{r}\end{array}$ & Apr & Mei & Jun & Jul & Agt & Sep & Okt & Nov & Des \\
\hline \multirow[t]{2}{*}{ 2016-2017 } & 0,08 & 0,08 & 0,02 & 0,03 & $\overline{-}$ & 0,07 & 0,09 & 0,00 & 0,05 & 0,06 & $\overline{-}$ & 0,04 \\
\hline & 0 & 2 & 6 & $\begin{array}{l}1 \\
-\end{array}$ & 8 & $\begin{array}{l}4 \\
-\end{array}$ & 9 & 1 & $\begin{array}{l}3 \\
-\end{array}$ & 3 & 5 & 5 \\
\hline \multirow[t]{3}{*}{ 2017-2018 } & 0,00 & 0,05 & 0,00 & 0,02 & 0,06 & 0,08 & 0,12 & 0,01 & 0,00 & 0,05 & 0,03 & 0,06 \\
\hline & 4 & 6 & 8 & 9 & 6 & 3 & 1 & 0 & 9 & 2 & 4 & 1 \\
\hline & 0,25 & 0,01 & 0,00 & 0,05 & 0,06 & 0,05 & 0,01 & 0,16 & 0,04 & 0,01 & 0,04 & 0,02 \\
\hline 2018-2019 & 7 & 7 & 1 & $\begin{array}{l}2 \\
-\end{array}$ & $\begin{array}{l}1 \\
-\end{array}$ & $\begin{array}{l}5 \\
-\end{array}$ & 1 & 9 & 4 & 8 & $\begin{array}{l}0 \\
-\end{array}$ & 3 \\
\hline $\mathbf{A C A R}_{W I N}$ & 0,34 & 0,15 & $\mathbf{0 , 0 3}$ & 0,05 & 0,06 & 0,06 & 0,23 & 0,18 & $\mathbf{0 , 0 8}$ & 0,13 & $\mathbf{0 , 0 0}$ & 0,12 \\
\hline$N E R$ & 1 & 5 & 3 & $\mathbf{0}$ & 4 & 4 & 1 & $\mathbf{0}$ & 9 & 3 & 1 & 9 \\
\hline Std & 0,13 & 0,03 & 0,01 & 0,04 & 0,07 & 0,08 & 0,05 & 0,09 & 0,03 & 0,02 & 0,06 & 0,01 \\
\hline \multirow[t]{2}{*}{ Deviasi } & 0 & 3 & 4 & $\begin{array}{l}3 \\
-\end{array}$ & $\begin{array}{l}5 \\
-\end{array}$ & $\begin{array}{l}4 \\
-\end{array}$ & 8 & 5 & 4 & 3 & $\begin{array}{l}5 \\
-\end{array}$ & 9 \\
\hline & 1,51 & 2,73 & 1,38 & 0,67 & 0,48 & 0,44 & 2,29 & 1,10 & 1,51 & 3,27 & $\mathbf{0 , 0 0}$ & 3,90 \\
\hline \multirow[t]{2}{*}{ t-hitung } & 7 & 5 & 6 & 4 & 2 & 1 & 1 & 0 & 7 & 3 & 9 & 4 \\
\hline & - & - & - & - & - & - & - & - & - & - & - & - \\
\hline t-tabel & 2,92 & 2,92 & 2,92 & 2,92 & 2,92 & 2,92 & 2,92 & 2,92 & 2,92 & 2,92 & 2,92 & 2,92 \\
\hline$(5 \%, 2)$ & 0 & $\mathbf{0}$ & 0 & 0 & $\mathbf{0}$ & 0 & 0 & 0 & 0 & $\mathbf{0}$ & 0 & 0 \\
\hline
\end{tabular}

Sumber: data diolah, 2020

Perhitungan tabel di atas menunjukkan hasil t-hitung yang bernilai negatif terjadi pada bulan April, Mei, Juni dan November. ACAR winner yang bernilai negatif terbukti tidak signifikan dikarena hasil t-hitung $<$ t-tabel dan $\mathrm{H}_{0}$ dari hipotesis 1 diterima, yang artinya terjadinya market overreaction secara signifikan pada portofolio winner.

Perhitungan Tabel 3. menunjukkan hasil t-hitung yang bernilai positif yang ditandai warna biru terjadi pada bulan Januari dan Desember. Hasil t-hitung $<$ ttabel terjadi, maka $\mathrm{H}_{0}$ dari hipotesis 2 diterima sehingga secara signifikan tidak terjadinya market overreaction pada portofolio loser.

Perhitungan Tabel 4. menunjukkan hasil uji signifikansi t-hitung yang bernilai positif terjadi pada April, Mei dan Desember. Nilai t-hitung<t-tabel muncul, maka $\mathrm{H}_{0}$ dari hipotesis 3 diterima, sehingga tidak terbukti secara signifikan terjadinya market overreaction pada portofolio loser-winner. 
Hasil penelitian ketiga hipotesis tersebut membuktikan tidak terjadinya market overreaction pada IDX 30. Terbukti bahwa investor yang berinvestasi di pasar modal Indonesia sudah rasional dalam bertindak terhadap suatu informasi.

Tabel 3.

Pengujian Portofolio Loser

\begin{tabular}{|c|c|c|c|c|c|c|c|c|c|c|c|c|}
\hline \multirow{2}{*}{$\begin{array}{c}\text { Replikas } \\
\text { i }\end{array}$} & \multicolumn{12}{|c|}{ CAAR Loser } \\
\hline & Jan & Feb & Mar & Apr & Mei & Jun & Jul & Agt & Sep & Okt & Nov & Des \\
\hline \multirow{3}{*}{$\begin{array}{l}2016- \\
2017\end{array}$} & - & - & - & & - & - & - & - & - & & - & - \\
\hline & 0,10 & 0,01 & 0,06 & 0,02 & 0,01 & 0,02 & 0,09 & 0,01 & 0,07 & 0,00 & 0,07 & 0,01 \\
\hline & 5 & 9 & 0 & 0 & 8 & 8 & 2 & 3 & 8 & 2 & 8 & 8 \\
\hline \multirow{4}{*}{$\begin{array}{l}2017- \\
2018\end{array}$} & & - & - & - & - & - & - & - & - & - & - & \\
\hline & 0,16 & 0,05 & 0,07 & 0,02 & 0,00 & 0,07 & 0,16 & 0,04 & 0,14 & 0,07 & 0,02 & 0,04 \\
\hline & 5 & 3 & 7 & 5 & 5 & 7 & 3 & 2 & 0 & 1 & 5 & 5 \\
\hline & & - & - & - & - & - & - & - & & - & - & \\
\hline 2018- & 0,19 & 0,11 & 0,08 & 0,01 & 0,03 & 0,02 & 0,03 & 0,19 & 0,07 & 0,07 & 0,18 & 0,13 \\
\hline \multirow[t]{2}{*}{2019} & 4 & 0 & 2 & 4 & 1 & 8 & 2 & 6 & 6 & 0 & 6 & 1 \\
\hline & & - & - & - & - & - & - & - & - & - & - & \\
\hline $\operatorname{ACAR}_{L O}$ & 0,25 & 0,18 & 0,22 & $\mathbf{0 , 0 2}$ & 0,05 & 0,13 & 0,28 & 0,25 & 0,14 & 0,13 & 0,28 & 0,15 \\
\hline$S E R$ & 3 & 2 & 0 & 0 & 4 & 3 & 7 & 1 & 2 & 9 & 9 & 8 \\
\hline Std & 0,16 & 0,04 & 0,01 & 0,02 & 0,01 & 0,02 & 0,06 & 0,09 & 0,11 & 0,04 & 0,08 & 0,07 \\
\hline \multirow[t]{3}{*}{ Deviasi } & 5 & 6 & 2 & 3 & 3 & 8 & 6 & 8 & 1 & 2 & 2 & 5 \\
\hline & & - & - & - & - & - & - & - & - & - & - & \\
\hline & $\mathbf{0 , 8 8}$ & 2,28 & 10,9 & 0,46 & 2,39 & 2,71 & 2,52 & 1,47 & 0,73 & 1,91 & 2,03 & \\
\hline t-hitung & 9 & 5 & 64 & 8 & 8 & 4 & 7 & 3 & 7 & 7 & 4 & 1,22 \\
\hline t-tabel & 2,92 & 2,92 & 2,92 & 2,92 & 2,92 & 2,92 & 2,92 & 2,92 & 2,92 & 2,92 & 2,92 & 2,92 \\
\hline$(5 \%, 2)$ & 0 & 0 & 0 & 0 & 0 & 0 & 0 & 0 & 0 & 0 & 0 & 0 \\
\hline
\end{tabular}

Tabel 4.

Pengujian Portofolio Loser-winner

\begin{tabular}{|c|c|c|c|c|c|c|c|c|c|c|c|c|}
\hline \multirow{2}{*}{$\begin{array}{l}\text { Replik } \\
\text { asi }\end{array}$} & \multicolumn{12}{|c|}{ CAAR Loser-Winner } \\
\hline & Jan & Feb & $\begin{array}{c}\mathbf{M a} \\
\mathbf{r}\end{array}$ & Apr & Mei & Jun & Jul & Agt & Sep & Okt & Nov & Des \\
\hline \multirow{2}{*}{$\begin{array}{l}\text { 2016- } \\
2017\end{array}$} & 0,18 & $0,10^{-}$ & 0,08 & $0,01^{-}$ & 0,05 & $0,10^{-}$ & 0,19 & 0,01 & $0,13^{-}$ & 0,06 & $0,00^{-}$ & 0,06 \\
\hline & 5 & 1 & 6 & 1 & 0 & 2 & 1 & 5 & 1 & 2 & 3 & 3 \\
\hline \multirow{2}{*}{$\begin{array}{l}2017- \\
2018\end{array}$} & 0,16 & $0,10^{-}$ & $0,08^{-}$ & 0,00 & $0,0 \overline{-}$ & 0,00 & $0,28^{-}$ & 0,05 & $0,13^{-}$ & $0,12^{-}$ & $0,0 \overline{-}$ & 0,01 \\
\hline & 1 & 9 & 5 & 4 & 0 & 7 & 4 & 1 & 2 & 3 & 9 & 6 \\
\hline 2018- & 0,06 & 0,12 & 0,08 & 0,03 & 0,03 & 0,02 & 0,04 & 0,36 & 0,03 & 0,08 & 0,22 & 0,10 \\
\hline \multirow[t]{2}{*}{2019} & 3 & 7 & 1 & 8 & 0 & 7 & 3 & 5 & 2 & 8 & 6 & 8 \\
\hline & - & - & - & & & - & - & - & - & - & - & \\
\hline ACAR & 0,08 & $\mathbf{0 , 3 3}$ & 0,25 & $\mathbf{0 , 0 3}$ & 0,01 & 0,06 & $\mathbf{0 , 5 1}$ & $\mathbf{0 , 4 3}$ & 0,23 & 0,27 & 0,28 & 0,02 \\
\hline$(L-W)$ & 8 & 6 & 3 & 0 & 0 & 9 & 9 & 1 & 1 & 2 & 8 & 8 \\
\hline Std & 0,17 & 0,01 & 0,00 & 0,02 & 0,06 & 0,06 & 0,12 & 0,19 & 0,09 & 0,03 & 0,11 & 0,08 \\
\hline Deviasi & 5 & 3 & 3 & 5 & 4 & 9 & 2 & 3 & 4 & 1 & 6 & 8 \\
\hline
\end{tabular}


Lanjutan Tabel 4.

\begin{tabular}{lrrrrrrrrrrrr}
\hline \multirow{2}{*}{$\begin{array}{l}\text { Replika } \\
\text { si }\end{array}$} & Jan & Feb & Mar & Apr & Mei & Jun & Jul & Agt & Sep & Okt & Nov & Des \\
\hline t- & - & - & - & & & & - & - & - & - & - & - \\
hitu & 0,28 & 1,46 & 5,49 & $\mathbf{0 , 7 1}$ & $\mathbf{0 , 0 9}$ & 0,56 & 2,46 & 1,29 & 1,41 & 5,14 & 1,43 & $\mathbf{0 , 1 9}$ \\
ng & 6 & 1 & 9 & $\mathbf{3}$ & $\mathbf{0}$ & 5 & 1 & 3 & 3 & 9 & 3 & $\mathbf{0}$ \\
\hline t- & & & & & & & & & & & & \\
tabel & & & & & & & & & & & & \\
$(\mathbf{5 \%}$, & $\mathbf{2 , 9 2}$ & $\mathbf{2 , 9 2}$ & $\mathbf{2 , 9 2}$ & $\mathbf{2 , 9 2}$ & $\mathbf{2 , 9 2}$ & $\mathbf{2 , 9 2}$ & $\mathbf{2 , 9 2}$ & $\mathbf{2 , 9 2}$ & $\mathbf{2 , 9 2}$ & $\mathbf{2 , 9 2}$ & $\mathbf{2 , 9 2}$ & $\mathbf{2 , 9 2}$ \\
$\mathbf{2}$ & $\mathbf{0}$ & $\mathbf{0}$ & $\mathbf{0}$ & $\mathbf{0}$ & $\mathbf{0}$ & $\mathbf{0}$ & $\mathbf{0}$ & $\mathbf{0}$ & $\mathbf{0}$ & $\mathbf{0}$ & $\mathbf{0}$ & $\mathbf{0}$ \\
\hline
\end{tabular}

Sumber: data diolah, 2020

Para investor tidak lagi memanfaatkan strategi kontarian untuk memperoleh keuntungan karena pasar modal Indonesia sudah menjadi pasar yang efisien.

Pasar modal Indonesia sudah menunjukkan pasar efisien dalam bentuk lemah. Investor tidak dapat memanfaatkan informasi data histori untuk memperoleh keuntungan abnormal. Hasil pengujian hipotesis 1 yaitu $\mathrm{ACAR}_{\mathrm{W}}>0$, hipotesis 2 $\mathrm{ACAR}_{\mathrm{L}}<0$ dan hipotesis $3 \mathrm{ACAR}_{(\mathrm{L}-\mathrm{W})}<0$, yang menunjukan konsistensi terhadap penelitian Hadimas (2019) secara statsitik hasil penelitiannya menunjukkan bahwa tidak terjadi overreaction pada LQ 45 periode 2014-2018 pada portofolio ACAR winner, ACAR loser, dan ACAR (L-W) sehingga pelaku investasi tidak dapat memanfaatlan startegi kontrarian khususnya pada LQ 45.

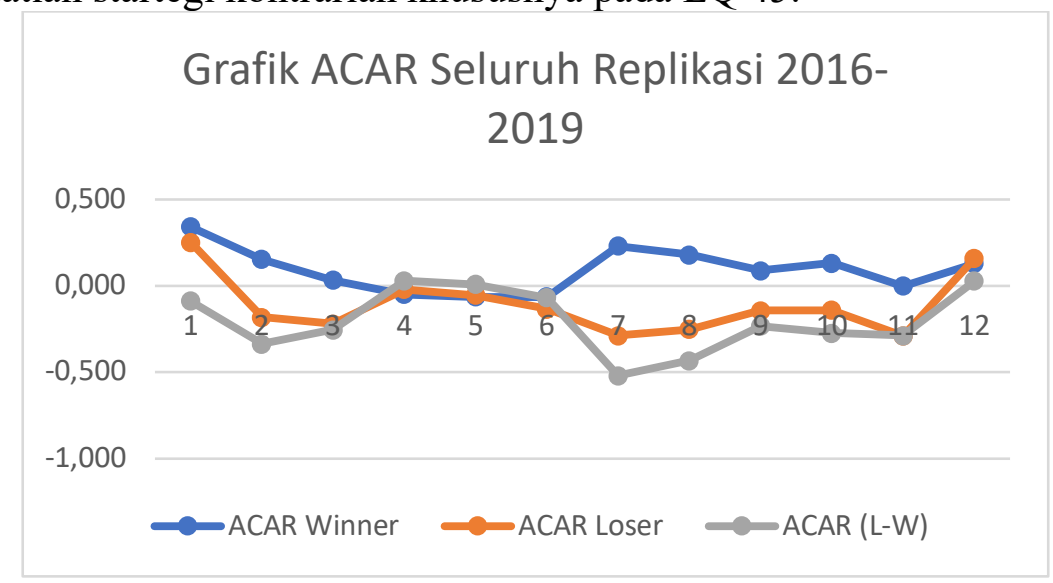

\section{Gambar 6.Grafik ACAR Seluruh Replikasi}

Sumber: Data diolah, 2020

Gambar di atas menunjukan ACAR seluruh replikasi. Terlihat jelas bahwa terdapat pembalik harga (Price Reversal) pada ACAR winner, ACAR loser dan ACAR(L-W), namun dari hasil pengujian di atas menunjukan bahwa ACAR winner, ACAR loser dan ACAR (L-W) yang mengalami pembalik harga tidaklah signifikan yang artinya terjadi market overreaction tetapi tidak signifikan.

Konsisiten dengan hasil penelitian (Amelia \& Wijayanto, 2018) melakukan pengujian terahadap perusahaan pertambangan yang terdaftar pada Bursa Efek Indonesia periode 2013-2017. Hasil penelitian mereka menunjukkan terjadinya market overreaction tetapi tidak signifikan yang ditandai dengan hasil output dari uji one sample t-test. Signifikansi ACAR portofolio winner sebesar 0,211>0,05. Signifikansi ACAR loser sebesar 0,656 > 0,05, dan signifikansi ACAR (L-W) 
sebesar $0,110>0,05$, artinya fenomena overreaction pada perusahaan pertambangan di Bursa Efek Indonesia tidak ditemukan.

Konsisten dengan hasil penelitian dari (Zakir R et al., 2019) hasil penelitian mereka yang meneliti saham perusahaan manufaktur yang terdaftar di (BEI) periode 2015-2017, menyimpulkan bahwa kinerja portofolio loser tidak mengungguli portofolio pemenang kinerja selama masa studi.

Konsisten dengan hasil penelitian dari (Rahmah, 2018) meneliti saham BUMN (IDX BUMN20) dan Non BUMN 2013-2017, hasilnya tidak terjadi pembalikan return secara signifikan pada saham BUMN baik porotofolio winner maupun loser. Sebaliknya terjadi pembalikan return secara signifikan pada saham Non BUMN di beberapa periode pengujian.

Konsisten dengan hasil penelitian dari (Novisiantara et al., 2017)Overreaction tidak terjadi pada saham perusahaan manufaktur dalam indeks LQ-45 dapat dibuktikan dengan pola portofolio winner mengungguli portofolio loser. Konsisten dengan hasil penelitian yang dilakukan oleh (Puspitasari et al., 2020) menguji overreaction terhadap harga saham setelah adanya pengumuman work from home pada LQ 45 Hasil pengujian ini juga menunjukkan bahwa portofolio loser tidak mengungguli portofolio winner.

Konsisten dengan hasil penelitian yang dilakukan oleh (Dewanthi \& Wiksuana, 2017) yang melakukan penelitian pada indeks Bisnis-27 periode 2016. Hasil pengujian yang dilakukannya menyatakan bahwa hasil penelitiannya tidak menemukan overreaction yang signifikan secara statistik menggunakan uji independent sample t-test pada objek Indeks BISNIS-27 periode 2016, secara signifikan ditandai dengan adanya rata-rata statistik abnormal return portofolio winner unggul sebesar $(0,0442)$ dari abnormal return portofolio loser sebesar (0,0123).

Konsisten dengan hasil penelitian yang dilakukan oleh (Surya Pratama, 2016) hasil penelitiannya menunjukkan tidak terdapat market overreaction pada perusahaan manufaktur di tahun 2014, yang ditandai abnormal return saham winner lebih besar dibandingkan dengan abnormal return saham loser secara signifikan. Pasar modal Indonesia dapat dinyatakan sudah efisien.

Market overreaction merupakan suatu anomali yang bertentangan dengan efficient market hypothesis, dimana event study digunakan untuk menguji market overreaction dalam bentuk pasar semi-strong. Hasil penelitian ini menyatakan bahwa terjadinya overreaction yang di tandai dengan adanya pembalik harga yang tidak signifikan pada setiap hipotesis ACAR winner, ACAR loser dan ACAR (LW). Hasil penelitian ini membuktikan konsistensi terhadap teori Efficient Market Hypothesis yang dikemukakan oleh Fama (1970) menyatakan bahwa pasar efisien adalah pasar yang dimana harga sekuritasnya sudah mencerminkan seluruh informasi yang relevan dengan pasar sehingga dalam kondisi ini tidak adanya market overreaction. Berdasarkan hal tersebut, pasar modal Indonesia dapat dinyatakan efisien dalam bentuk semi kuat sehingga pasar modal Indonesia bertentangan dengan hasil penelitian Debond dan Thaler (1985), sehingga strategi kontrarian tidak dapat di manfaatkan untuk memperoleh abnormal return. Behavior finance sangat berpengaruh terhadap pergerakan harga saham.

Hasil penelitian ini menunjukkan bahwa tidak terdapat market overreaction 
yang signifikan di BEI yang berarti pasar modal Indonesia telah menjadi pasar yang efisien. Hal ini menandakan bahwa Pasar modal Indonesia telah meningkatkan infrastruktur khususnya infrastruktur terkait penyampaian informasi yang akurat dan relevan terhadap pasar modal, sehingga informasi di pasar modal selalu up to date dan lebih efisien. Pasar modal Indonesia sudah menetapkan aturan batas atas dan batas bawah (Price limit) pergerakan suatu saham yang mampu mengurangi tingginya volatilitas akibat overreaction investor.

Hasil penelitian menunjukkan tidak ada reaksi pasar yang berlebihan di BEI, sehingga investor tidak bisa memanfaatkan strategi kontrarian untuk memperoleh abnormal return, hal tersebut menunjukkan adanya fluktuasi pergerakan ACAR winner, ACAR loser dan ACAR (L-W) yang melewati angka 0 namun pergerakan harga yang berbalik tersebut dinyatakan tidak signifikan terjadinya market overreaction yang terjadi pada indeks IDX 30 periode 2016-2019.

Terjadinya market overreaction ditunjukkan dengan pembalikan harga saham. Perusahaan diharapkan dapat meningkatkan kinerja operasional perusahaanya sebagai tolak ukur bagi investor dalam menganalisis harga saham perusahaan. Perusahaan sebaiknya lebih tanggap dan cermat mengenai informasi yang terpublikasikan guna mengantisipasi perubahan harga saham perusahaan Keterbatasan dari penelitian ini terletak pada wilayah penelitian yang hanya menggunakan perusahaan yang tergolong dalam indeks IDX 30 saja.

Penelitian selanjutnya diharapkan dapat menggunakan wilayah penelitian yang lebih luas, rentang periode penelitian ini terbilang cukup singkat yaitu selama 4 tahun periode penelitian, diharapkan penelitian berikutnya dapat menggunakan periode penelitian yang lebih lama unuk dapat memperoleh hasil yang lebih jelas dan akurat mengenai keadaan pasar modal Indonesia. Metode penelitian yang digunakan pada penelitian ini adalah market adjusted model, diharapkan penelitian berikutnya dapat menggunakan metode mean adjusted return atau market model dalam menghitung abnormal return agar dapat memperoleh hasil yang lebih akurat mengenai overreaction pada pasar modal Indonesia.

\section{SIMPULAN}

Berdasarkan pada pemabahasan dan analisis yang telah dijelaskan pada babbab sebelumnya mengenai market overreaction pada IDX 30 periode 2016-2019, maka dapat ditarik kesimpulkan bahwa portofolio pemenang atau pecundang terlihat beberapa kali mengalami gejala pembalikan harga pada saham yang tercatat di Indeks IDX30 di Bursa Efek Indonesia selama periode penelitian 2016-2019 namun secara statistik tidak signifikan, yang berarti tidak terjadi reaksi berlebihan di pasar modal Indonesia.

Hasil penelitian ini konsisten dengan teori efficient market hypothesis dimana event study digunakan untuk menguji market overreaction dalam bentuk pasar semi-strong, sehingga pasar modal Indonesia sudah dalam kondisi setengah kuat. Hasil penelitian ini tidak konsisten dengan penelitian yang dilakukan oleh Debont dan Thaler.

Strategi investasi kontarian tidak dapat digunakan secara intensif oleh investor karena dapat mengakibatkan investor mengalami kerugian Pasar modal Indonesia sudah menunjukan pasar efisien dalam bentuk lemah atau semi kuat. 
Investor tidak dapat memanfaatkan informasi data histori untuk memperoleh keuntungan abnormal. Investor Indonesia harus aktif dalam berinvestasi dan menganalisis informasi yang ada secara canggih dan tepat untuk menentukan keputusan investasi yang tepat untuk memperoleh keuntungan. Berdasarkan pada pemabahasan sebelumnya beserta simpulan diatasa, maka saran untuk investor dan penelitian selanjutnya mengenai overreaction sebagai berikut, bagi peneliti selanjutnya disarankan dapat mencoba menggunakan metode perhitungan abnormal return menggunakan mean adjusted model dan market model yang tingkat kesulitannya lebih tinggi. Kemudian disarankan untuk melakukan penelitian pada indeks lainnya atau sektor di Bursa Efek Indonesia dan untuk faktor anomali efisiensi pasar agar dapat lebih dikontrol dalam penelitian selanjutnya terutama dalam pemilihan sampel, agar hasil penelitian yang di peroleh lebih baik dan valid.

Keterbatasan penelitian ini yaitu penggunaan sampel yang masih relative kecil dan periode penelitian yang singkat. Untuk penelitian selanjutnya diaharapkan dapat menggunakan objek penelitian yang lebih besar dan periode penelitian yang lebih panjang untuk memperoleh hasil yang lebih jelas mengenai keadaan investasi di Bursa Efek Indonesia mengenai reaksi pasar dengan cakupan yang lebih luas. Bagi investor sebaiknya tidak menerapkan strategi kontarian karena mengingat fakta tidak terbukti secara statistik overreaction terjadi pada portofolio winnerloser. Apabila investor ingin menerapkan strategi kontarian di Bursa Efek Indonesia ada baiknya investor juga mempelajari behavioral finance dan lebih teliti menganalisis informasi yang ada, karena memang investor bertindak secara irasional dapat menyebabkan overreaction.

\section{REFERENSI}

Abidin, F. (2020). 3,1 Juta Investor Pasar Modal, Naik 2,6 Persen Selama Pandemi. IDX Chanyel. https://www.idxchannel.com/market-news/31-jutainvestor-pasar-modal-naik-26-persen-selama-pandemi

Alves, P. (2020). Recent Evidence on International Stock Markets Overreaction. 97983.

Amelia, R., \& Wijayanto, A. (2018). The Winner Loser Anomaly In Indonesia. Management Analysis Journal, 7(2), 1-6.

Caporale, G. M., \& Plastun, A. (2019). Price overreactions in the cryptocurrency market. Journal of Economic Studies, 46(5), 1137-1155. https://doi.org/10.1108/JES-09-2018-0310

De Bondt, W. F. M., \& Thaler, R. (1985). Does the Stock Market Overreact? The Journal of Finance, 40(3), 793-805. https://doi.org/10.1111/j.15406261.1985.tb05004.x

Dewanthi, P. T., \& Wiksuana, I. G. B. (2017). Analisis Overreaction Saham Winner - Loser Pada Perusahaan Indeks BISNIS - 27 Di Bursa Efek Indonesia. EJurnal Ekonomi Dan Bisnis Universitas Udayana, 11, 3951. https://doi.org/10.24843/eeb.2017.v06.i11.p08 
Fama, E. F. (1970). Session Topic: Stock Market Price Behavior Session Chairman: Burton G. Malkiel Efficient Capital Markets: A Review Of Theory And Empirical Work. The Journal of Finance, 25(2), 383-417.

Gumanti, T. A., Kasprianti, M. D., \& Mufidah, A. (2019). Market Overreaction Saham Lq-45 Terhadap Pengumuman Asian Games Ke-18. Wahana: Jurnal Ekonomi, Manajemen Dan Akuntansi, 22(2), 186-203. https://doi.org/10.35591/wahana.v22i2.157

Hadimas, H. (2019). Overreaction Anomaly Di Pasar Modal Indonesia (Studi Pada Saham-Saham Lq-45 Tahun 2014-2018). Journal of Business Economics, 24(1), 88-99. https://doi.org/10.35760/eb.2019.v24il.1857

Hartono, J. (2017). Teori Portofolio dan Analisis Investasi (Edisi 11). BPFE.

Investing.com. (2020). Data IHSG. Www.Investing.Com. https://www.investing.com/indices/idx-composite-historical-data

Joshua Duta Wacana, C. M. F. (2017). ANALISIS OVERREACTION PADA SAHAM-SAHAM LQ-45 DI BURSA EFEK INDONESIA. 27-38.

Lerskullawat, P., \& Ungphakorn, T. (2019). Does overreaction still exist in Thailand? Kasetsart Journal of Social Sciences, 40(3), 689-694. https://doi.org/10.1016/j.kjss.2018.02.001

Maheshwari, S., \& Dhankar, R. S. (2017). Momentum anomaly: evidence from the Indian stock market. Journal of Advances in Management Research, 14(1), 3-22. https://doi.org/10.1108/JAMR-11-2015-0081

Melisa Tanady, S. S. (2020). Market Overreaction Pada Bursa Efek Indonesia Dengan Size Effect Sebagai Variabel Pemoderasi. 9(3), 206-217.

Musnadi, S., Faisal, \& Majid, M. S. A. (2018). Overreaction and underreaction anomalies in the Indonesian stock market: a sectoral analysis. International Journal of Ethics and Systems, 34(4), 442-457. https://doi.org/10.1108/IJOES-12-2017-0235

Nidar, S. R., \& Ulfa, N. (2017). Overreaction Market Analysis, Dividend Policy, Firm Size, and Seasonality to Price Reversal Phenomena. Accounting and $\begin{array}{llll}\text { Finance } & \text { Review, } & \text { 73-77. }\end{array}$ https://econpapers.repec.org/RePEc:gtr:gatrjs:afr136

Novisiantara, I. D., Masyithoh, S., \& Setiawati, L. (2017). Analisis Overreaction Pada Harga Saham Perusahaan Manufaktur. JURNAL MANAJEMEN, 9(1), 31-37. http://journal.feb.unmul.ac.id/index.php/jurnalmanajemen 
Pedro Piccoli, M., \& Chaudhury, Alceu Souza, W. V. da S. (2019). Stock Overreaction to Extreme Market Events. North American Journal of Economics and Finance. Sustainability (Switzerland), 11(1), 1-14. http://scioteca.caf.com/bitstream/handle/123456789/1091/RED2017-Eng8ene.pdf? sequence $=12 \&$ isAllowed $=\mathrm{y} \% 0 \mathrm{~A}$

Pokavattana, N., Sethjinda, T., \& Tangjitprom, N. (2019). The over-reaction effect in the Stock Exchange of Thailand: An empirical study. Journal of Community Development Research (Humanities and Social Sciences), 12(3), 92-106.

Praditha, R., Haliah, Habbe, A. H., \& Rura, Y. (2019). Market Overreaction on LQ45 Stock Index before and after Asian Games 2018. 9(2), 117-125. https://doi.org/10.6007/IJARAFMS/v9-i2/6047

Puspitasari, A. P., Atahau, A. D. R., \& ... (2020). Potensi Overreaction Terhadap Harga Saham Setelah Pengumuman Work From Home. Jurnal Manajemen, 10. http://journal.umpo.ac.id/index.php/ASSET/article/view/2920

Rahmah, F. H. (2018). Analisis Overreaction Pada Saham BUMN dan Non BUMN Di Indonesia.

Reddy, K., Qamar, M. A. J., Mirza, N., \& Shi, F. (2020). Overreaction effect: evidence from an emerging market (Shanghai stock market). International Journal of Managerial Finance. https://doi.org/10.1108/IJMF-01-2019-0033

Sembiring, F. M., Rahman, S., Effendi, N., \& Sudarsono, R. (2016). Capital Asset Pricing Model In Market Overreaction Conditions: Evidence From Indonesia Stock Exchange. Polish Journal of Management Studies, 14(2), 182-191. https://doi.org/10.17512/pjms.2016.14.2.17

Shafiq-ur-Rehman, B. S. (2019). Analysis of Investor Overreaction Effect and Random Walk: A Case Study Of Pakistan stock Exchange. 5(1), 1-14.

Surya Pratama, I. G. (2016). Analisis Overreaction Pasar Pada Saham Winner dan Loser Bursa efek Indonesia. 12, 4387-4414.

Tandelilin, E. (2017). Pasar Modal Manajemen Portofolio dan Investasi. PT. Kanisius.

Utama, S. (2016). Aplikasi Analisis Kuantitatif. CV. Sastra Utama.

Zakir R, E. K. Z., Afifudin, \& Junaidi. (2019). Analisis Overreaction Pada Saham Perusahaan Manufaktur yang Terdaftar di BEI Periode 2015-2017. 08(07), 123-135. 